\title{
Direct and Indirect Effect of Honey as a Functional Food Against Metabolic Syndrome and Its Skeletal Complications
}

This article was published in the following Dove Press journal: Diabetes, Metabolic Syndrome and Obesity: Targets and Therapy

\author{
Elvy Suhana Mohd Ramli' \\ Kumeshini Sukalingam' \\ Mohd Amir Kamaruzzaman' \\ Ima Nirwana Soelaiman ${ }^{2}$ \\ Kok-Lun Pang (iD ${ }^{2}$ \\ Kok-Yong Chin $\mathbb{D}^{2}$ \\ 'Department of Anatomy, Faculty of \\ Medicine, Universiti Kebangsaan Malaysia \\ Medical Centre, Cheras, Kuala Lumpur, \\ Malaysia; ${ }^{2}$ Department of Pharmacology, \\ Faculty of Medicine, Universiti \\ Kebangsaan Malaysia Medical Centre, \\ Cheras, Kuala Lumpur, Malaysia
}

\begin{abstract}
Metabolic syndrome (MetS) refers to the simultaneous presence of hypertension, hyperglycemia, dyslipidemia and/or visceral obesity, which predisposes a person to cardiovascular diseases and diabetes. Evidence suggesting the presence of direct and indirect associations between MetS and osteoporosis is growing. Many studies have reported the beneficial effects of polyphenols in alleviating MetS in in vivo and in vitro models through their antioxidant and anti-inflammation actions. This review aims to summarize the effects of honey (based on unifloral and multi-floral nectar sources) on bone metabolism and each component of MetS. A literature search was performed using the PubMed and Scopus databases using specific search strings. Original studies related to components of MetS and bone, and the effects of honey on components of MetS and bone were included. Honey polyphenols could act synergistically in alleviating MetS by preventing oxidative damage and inflammation. Honey intake is shown to reduce blood glucose levels and prevent excessive weight gain. It also improves lipid metabolism by reducing total cholesterol, triglycerides and low-density lipoprotein, as well as increasing high-density lipoprotein. Honey can prevent bone loss by reducing the adverse effects of MetS on bone homeostasis, apart from its direct action on the skeletal system. In conclusion, honey supplementation could be integrated into the management of MetS and MetS-induced bone loss as a preventive and adjunct therapeutic agent.
\end{abstract}

Keywords: antioxidant, anti-inflammatory, bone, hypertension, hyperlipidemia, hyperglycemia, obesity, osteoporosis

\section{Introduction}

Metabolic syndrome (MetS) is a non-communicable disease characterized by a cluster of medical conditions, such as visceral obesity, diabetes mellitus, dyslipidemia, and/or hypertension, which predispose an individual to cardiovascular diseases and diabetes mellitus. ${ }^{1}$ Prevalence of MetS ranges from $<10 \%$ to as high as $84 \%,{ }^{2,3}$ affecting 33\% of the adult population in the USA between 2003 and 2012 and $25.7 \%$ of adults in the Asia-Pacific region. ${ }^{4}$ The incidence of MetS often parallels with the onset of obesity and type 2 diabetes, but it is dependent on the diagnostic criteria and definition of MetS used. ${ }^{5}$ The underlying etiology of MetS is still not completely understood, but rapid urbanization of developing countries, consumption of unhealthy diet and sedentary lifestyle are known to contribute to MetS. ${ }^{6}$ Westernization of lifestyle is closing the prevalence gap between Asian and Western countries. ${ }^{7,8}$ Additionally, age, sex, ethnicity, family inheritance (genetic
Correspondence: Elvy Suhana Mohd Ramli Department of Anatomy, Faculty of Medicine, Universiti Kebangsaan Malaysia Medical Centre, Level 18, Preclinical Building, Jalan Yaacob Latif, Bandar Tun Razak, Cheras 56000, Kuala Lumpur, Malaysia

Tel +60391458633

Email elvysuhana@ukm.edu.my
Diabetes, Metabolic Syndrome and Obesity: Targets and Therapy 2021:14 24I-256 
susceptibility), chronic inflammation and gut microbiota are also associated with the onset of MetS. ${ }^{9-12}$

According to the Joint Interim Statement (2009), MetS is diagnosed when a patient has at least three out of five conditions: (1) high fasting blood glucose (FBG) ( $\geq 100 \mathrm{mg} / \mathrm{dL}$ or receiving drug therapy for hyperglycemia); (2) high blood pressure $(\geq 130 / 85 \mathrm{mmHg}$ or receiving drug therapy for hypertension); (3) high serum triglycerides (TG) ( $\geq 150 \mathrm{mg} /$ $\mathrm{dL}$ or receiving drug therapy for hypertriglyceridemia); (4) low serum high-density lipoprotein cholesterol (HDL) $(<40 \mathrm{mg} / \mathrm{dL}$ in men or $<50 \mathrm{mg} / \mathrm{dL}$ in women, or receiving drug therapy for reduced HDL); and (5) the presence of central obesity [waist circumference $\geq 102 \mathrm{~cm}$ (40 inches) for Europid men or $\geq 88 \mathrm{~cm}$ ( 35 inches) for Europid women; $\geq 90 \mathrm{~cm}$ ( 35 inches) for Asian men or $\geq 80 \mathrm{~cm}$ (32 inches) for Asian women]. ${ }^{1}$ Proper management or prevention of MetS will lower the risk for its complications, including cardiovascular diseases and diabetes mellitus. ${ }^{10}$ The current approach in MetS treatment focuses on lifestyle modification or management, such as calorie restriction, low-to-moderate intense and regular aerobic physical activity and resistance training program. ${ }^{10}$ The patients will be prescribed medications, such as beta-blockers/angiotensin-converting enzyme inhibitors for hypertension, statins for hyperlipidemia, metformin/glibenclamide for hyperglycemia if lifestyle modifications are insufficient. ${ }^{13}$ Although these agents are successful in controlling the components of MetS, concurrent use will lead to the issues of polypharmacy, leading to problems such as high medical expenses, drug interactions, low compliance of the patients. ${ }^{14}$ To date, no single treatment targeting all the components of MetS is available in the market.

MetS is associated with oxidative stress and chronic inflammation which underlay various diseases. The cellular catabolism of excess nutrients generates oxidative stress due to mitochondrial dysfunction and endoplasmic reticulum stress, which can subsequently cellular damage and malfunction. ${ }^{15,16}$ Adipose secretion of proinflammatory cytokines, such as interleukin (IL)-1, IL-6 and tumor necrosis factor-alpha (TNF $\alpha)$, and activation of nuclear factor kappa-B (NF- $\mathrm{B}$ ) pathway by ligands for Toll-like receptors and receptors of advanced glycation end products produce chronic inflammation in MetS. ${ }^{17-19}$ MetS is also linked to hyperactivation of the hypothalamic-pituitary-adrenal axis as a result of increased inflammation and leptin level. ${ }^{20}$ These intervening physiological changes give rise to many pathological conditions. For instance, biological toxicity due to oxidative stress and protein glycation could cause microvascular dysfunction, which subsequently leads to hippocampal neuronal degeneration and cognitive deficit. $^{21}$ Oxidative stress, chronic inflammation and hypercortisolism in MetS augment insulin resistance. Hypercortisolism is also implicated in affective disorders, especially depression. ${ }^{22,23}$

The current review focuses on the adverse effects of MetS on bone. Osteoporosis is a metabolic bone disease characterized by a reduction in bone mass and deterioration in bone microstructure, leading to skeletal fragility and increased susceptibility to fracture. ${ }^{24}$ It is typically defined in men or women with a bone mineral density (BMD) T-score lower than 2.5 standard deviations of the young adult populations (T-score $\leq-2.5$ ) ${ }^{25}$ Aging, menopause or other secondary factors, such as calcium malabsorption, glucocorticoid treatment, immobility and chronic inflammatory diseases increase the risk of osteoporosis. ${ }^{26}$ Accumulated evidence revealed the indirect association of MetS in osteoporosis. Constituents of MetS such as dyslipidemia, abdominal obesity, hyperglycemia and hypertension are co-expressed in individuals with osteopenia or osteoporosis. $^{27-29}$ The association of MetS with low BMD and osteoporosis had been demonstrated in systematic review and meta-analysis. ${ }^{28-30}$

Chronic low-grade inflammation and oxidative stress present in MetS play major roles in inducing osteoporosis or bone loss. ${ }^{28}$ The inflammatory-related signaling pathways like NF- $\kappa \mathrm{B}$ and mitogen-activated protein kinases (MAPKs) are activated during MetS. ${ }^{31}$ Activated NF-kB upregulates several downstream proinflammatory mediators such as cyclooxygenase-2 (COX-2), IL-6, IL-12, interferon, TNF- $\alpha$ and inducible nitric oxide synthase. ${ }^{32,33}$ Besides, reactive oxygen species (ROS) is generated during MetS due to excessive macronutrients intake and inflammation. ${ }^{28,34,35}$ ROS like hydrogen peroxide also reciprocally promotes the oxidative activation and self-amplification of the inflammatory response. ${ }^{34,35}$ Eventually, the oxidative stress and inflammation events promote the osteoclastogenesis and inhibit the osteoblastogenesis, thereby affecting bone homeostasis and causing bone loss. ${ }^{28}$

Natural products consumed by humans since antiquity offer safe and economical dietary options to treat or prevent several diseases and complications. They can be used as adjunct treatments to provide more comprehensive prevention or management against each component of MetS including obesity, hyperglycemia and dyslipidemia. ${ }^{36}$ Honey is a natural product with health-beneficial effects 
due to its potent antioxidant and anti-inflammatory properties. Honey is a sweet viscous fluid stored in wax-form structures called honeycombs after being harvested by honeybees from plants (floral nectar). ${ }^{37}$ It is produced through regurgitation, enzymatic activity, and water evaporation in the beehives. Apart from the nectar source, honeybees also collect secretions from insects (belonging to the genus Rhynchota) to produce honeydew honey. ${ }^{37}$ Honey is composed of at least 181 substances, mainly carbohydrates like fructose (38\%) and glucose (31\%). It also contains enzymes, amino acids, vitamins, proteins and polyphenols. ${ }^{38}$ The antioxidant property of honey is contributed by its polyphenol content, which is comprised of flavonoids (eg, quercetin, luteolin, kaempferol, apigenin, chrysin, galangin), phenolic acids, antioxidant enzymes (eg, glucose oxidase and catalase, CAT), ascorbic acid, and carotenoids. ${ }^{38-40}$

Honey polyphenols are responsible for various pharmacological effects by suppressing ROS formation through inhibition of enzymes or chelating trace elements involved in free radical generation. ${ }^{41,42}$ Additionally, honey also exerts anti-inflammatory properties as reported by several in vitro and in vivo studies. ${ }^{37,43}$ In carrageenan-induced inflammation model, honey acts as an anti-inflammatory agent by inhibiting the production of proinflammatory mediators, such as nitric oxide (NO), prostaglandin $\mathrm{E}_{2}\left(\mathrm{PGE}_{2}\right)$, TNF- $\alpha$, and IL- 6 . $^{43-45}$ The biological actions of NF- $\kappa B$, including the activation of transcription and DNA binding activity, are regulated by the acetylation and subsequent nuclear translocation of NF- $\mathrm{BB}$ p65 subunit. ${ }^{46}$ Honey also inhibits $\mathrm{NF}-\kappa \mathrm{B}$ inhibitor- $\alpha(\mathrm{I} \kappa \mathrm{B} \alpha)$ degradation and subsequently attenuates NF- $\kappa$ B nuclear translocation. ${ }^{47}$ Gallic acid, a type of phenolic acids found in honey, also exerts an anti-inflammatory action by suppressing $\mathrm{NO}, \mathrm{PGE}_{2}$ and IL-6 production in lipopolysaccharide-induced RAW 267.4 murine macrophages. ${ }^{48}$ Gallic acid inhibits p65 acetylationdependent activation of $\mathrm{NF}-\kappa \mathrm{B}$ and the production of inflammatory mediators. ${ }^{49}$ All of the bioactive compounds in honey may act synergistically to contribute to its overall anti-inflammatory properties.

The pharmacological properties of honey have been investigated scientifically. Honey has antibacterial properties contributed by its phenolic content, hydrogen peroxide, $\mathrm{pH}$ and osmotic pressure. ${ }^{50}$ Honey facilitates wound healing, which is a property related to its antioxidant and antibacterial activity and osmotic pressure. Its high viscosity also maintains the moisture of the wound by forming a protective barrier. $^{38}$ Recent studies also demonstrated that honey exerts an antiproliferative effect against cancer cells. This effect is correlated with the phytochemical compounds of honey that activate the mitochondrial apoptotic pathways [62-65]. ${ }^{51-54}$ The effects of honey on metabolic disorders and skeletal health will be discussed further in later sections.

This review aimed to illustrate the pathogenesis of MetS and its relationship to osteoporosis. It also explores the beneficial effects of honey on each component of MetS and bone against deterioration caused by MetS.

\section{Methods}

A literature search was performed to identify relevant studies reporting the relationship between MetS or each MetS component on bone health. Two databases, ie, PubMed and Scopus, were searched without filtering years, language and type of publications. The search strategy involved a combination of the following sets of keywords, ie, (osteoporosis OR bone) AND (MetS OR hyperglycemia OR dyslipidemia OR hypertension OR obesity). In the subsequent search focusing on the effects of honey on MetS and bone health, the search string used was honey AND (osteoporosis OR bone) OR (MetS OR hyperglycemia OR dyslipidemia OR hypertension OR obesity). We only include original research articles in the current review. Articles were screened prior to their inclusion in this review.

\section{Honey and Obesity}

Obesity is a condition of excessive accumulation of body fat, and it is defined as having a body mass index (BMI) $\geq 30 \mathrm{~kg} / \mathrm{m}^{2} .{ }^{55}$ Central obesity is reflected by an increase in waist circumference due to the accumulation of visceral adipose tissue. ${ }^{56}$ Studies on the effects of obesity on osteoporosis showed contradictory findings. Obesity is traditionally thought to protect the skeleton against osteoporosis by exerting mechanical loading, which stimulates bone formation through decreasing apoptosis, increasing proliferation and differentiation of osteoblasts and osteocytes. $^{57-59} \mathrm{Wnt} / \beta$-catenin signaling pathway is suggested to govern this mechanism. ${ }^{60,61}$ Therefore, bone mass increases as a compensatory mechanism to accommodate the greater load. ${ }^{62}$ Insulin resistance associated with obesity also causes increased plasma insulin levels, contributing to androgen and estrogen overproduction in the ovary, and reduced production of sex hormone-binding globulin by the liver. ${ }^{63}$ The elevation of sex hormone levels reduces osteoclast activity and increases osteoblastogenesis, resulting in increased bone mass. ${ }^{64}$ 
However, recent reports demonstrated that excessive fat mass is associated with low total BMD and total bone mineral content. ${ }^{65-68}$ Obese mice fed with a high-fat diet showed decreased trabecular bone volume and cortical bone growth as revealed by micro-computed tomography (micro-CT) analysis. ${ }^{69}$ Another similar study also reported that obesity induced tibial trabecular microarchitectural destruction via increasing bone turnover, but it exerted minimal effects on cortical bone in high-fat diet-fed male mice. $^{70}$ Additionally, bone histomorphometric analysis also showed infiltration of adipocytes in the bone marrow of obese mice. ${ }^{71}$ These studies showed that obesity could be detrimental to bone health.

Several mechanisms underlying the harmful effects of obesity on the bone have been proposed. ${ }^{71}$ Firstly, both osteoblasts and adipocytes are derived from a common pool of mesenchymal stem cells. ${ }^{72}$ Agents that inhibit adipogenesis are found to stimulate osteoblast differentiation, ${ }^{73-75}$ and those that inhibit osteoblastogenesis could upregulate adipogenesis. ${ }^{76}$ Similarly, decreased bone marrow osteoblastogenesis in ageing is usually accompanied by increased marrow adipogenesis. ${ }^{77,78}$ This osteoblast-adipocyte shift causes a reduction of the osteoblasts available for osteogenesis. ${ }^{77,78}$ Bone marrow adipogenesis eventually leads to the expansion of the marrow cavity and cortical thinning. ${ }^{79}$

Secondly, as adipose tissue undergoes hypertrophy and hyperplasia due to the storage of unused energy, the blood supply to the tissue will reduce. ${ }^{80,81}$ A subsequent hypoxiamediated signaling pathway is triggered. It then further stimulates the production of proinflammatory mediators such as TNF- $\alpha$, IL-6, leptin, resistin and plasminogen activator inhibitor- $1 .{ }^{6}$ These proinflammatory mediators induce osteoclast differentiation and bone resorption through receptor activator of NF- $\mathrm{KB}$ (RANK)/RANK ligand (RANKL)/osteoprotegerin pathway. ${ }^{82,83}$

Thirdly, bone loss could occur due to the disruption of body energy regulation governed by adipocyte-derived hormones (leptin and adiponectin) and insulin during overnutrition or obesity. Leptin and adiponectin, which mainly regulate appetite and energy expenditures, also alter bone metabolism. ${ }^{84-86}$ These hormones regulate osteoblasts which expressed the leptin, adiponectin and insulin receptors. ${ }^{87-89}$ Peripheral leptin improves bone health by increasing estrogen while decreasing cortisol and glucocorticoid level. ${ }^{90}$ Besides, systemic administration of leptin to leptin-deficient and wild-type mice results in increased bone growth, skeletal mass and strength. ${ }^{64}$ On the other hand, leptin also regulates bone resorption through two distinct and antagonistic central neural pathways. ${ }^{91,92}$ Leptin-mediated sympathetic pathway promotes osteoclastogenesis by increasing the RANKL production by osteoblasts upon binding on the beta 2-adrenergic receptor. ${ }^{93,94}$ On the other hand, leptin also induces the production of cocaine amphetamine-regulated transcript (CART, a neuropeptide) in the hypothalamus, which could reduce osteoblast RANKL production. ${ }^{94}$

Protective effects of honey against obesity have been reported in animal studies. Rats fed with long-term and short-term honeydew honey (Northofagus solandrii) had a lower percentage of weight gain than those fed with sucrose and mixed sugars diet, although the total energy intake was similar between groups. ${ }^{95}$ In addition, dualenergy X-ray absorptiometry analysis showed that rats receiving long-term honey treatment had lower body fat. Nemoseck et al (2011) reported that rats given a diet containing $20 \%$ carbohydrate from clover honey had markedly lower weight gain and significantly reduced fat pad weight than rats fed with an isoenergetic diet from liquid sucrose. ${ }^{96}$ Anti-obesity effects of honey were also reported in randomized clinical trials (RCTs) in humans, whereby subjects receiving a daily $70 \mathrm{~g}$ honey for 1 month showed a reduction in body weight, fat weight and body fat percentage along with significantly decreased BMI. ${ }^{97}$ In another RCT by Bahrami et al (2009), the addition of honey in the diabetic treatment regime resulted in a significant reduction of the patients' body weight. ${ }^{98}$

The underlying mechanisms of anti-obesity and antiadipogenic effects of honey are not determined. The gradual reduction of fat mass by honey could be beneficial to the bone as adipose tissues are the primary source of proinflammatory cytokines and leptin. However, bone mass was not assessed in the studies mentioned.

\section{Honey and Dyslipidemia}

Atherogenic dyslipidemia is one of the core metabolic risk factors of MetS. The National Health and Nutrition Examination Survey (NHANES III) reports that $63 \%$ of patients with osteoporosis have hyperlipidemia. ${ }^{99}$ Individuals with mutations in low-density lipoprotein receptor-related protein 5 have low BMD and multiple spinal fractures. ${ }^{100}$ Diet- and apolipoprotein E deficiencyinduced hyperlipidemia affects bone health by reducing bone mass and trabecular structural parameters in femur and tibia. ${ }^{101-104}$ Micro-CT analysis in hyperlipidemic mice indicated a reduction in bone surface and bone volume with higher cortisol porosity, suggesting skeletal 
degenerative changes. ${ }^{104}$ Similarly, another study observed cortical and trabecular bone loss of the femur and vertebrae and decreased mechanical strength of the bones in mice with hypercholesterolemia. ${ }^{105}$ Proper management of hyperlipidemia was shown to improve bone health status. Various clinical and animal studies reported that cholesterol-lowering statin drugs reduce osteoporosis and fracture risk. ${ }^{106-109}$ The stimulatory role of statins in osteoblast differentiation and bone formation has been reported. ${ }^{110,111}$

Biochemical analysis of hyperlipidemic mice displayed increased serum parathyroid hormone (PTH), TNF- $\alpha$, C-terminal telopeptide of type-1 collagen (a bone resorption marker), calcium, and phosphorus levels. ${ }^{104}$ Simultaneously, amino-terminal propeptide of type-1 collagen (a bone formation marker) level was lower in hyperlipidemic mice. ${ }^{104}$ You et al (2011) reported that high cholesterol-fed rats showed decreased expression of genes involved in bone formation and increased expression of genes associated with bone resorption. ${ }^{112}$ Several bone formation genes are downregulated by high cholesterol diet, including transforming growth factor- $\beta$, bone morphogenetic proteins (BMPs) and Wnt family genes. ${ }^{113}$ Additionally, high cholesterol also increases bone turnover and reduces BMD with the concomitant increase of serum osteocalcin and carboxy-terminal collagen crosslinks. ${ }^{112,114-117}$

Oxidative injury is one of the mechanisms responsible for high-fat diet-induced osteoporosis. Atherogenic high-fat diets increase lipoprotein levels and their oxidative products. $^{118,119}$ The lipid oxidation products have been reported to present in the marrow of hyperlipidemic mice. ${ }^{120}$ Excessive lipid oxidation products including oxidized low-density lipoprotein attenuate the osteogenic differentiation of mesenchymal stem cells and preosteoblasts in favor of adipogenic differentiation. ${ }^{82,120-123}$ Additionally, free cholesterol reduces superoxide dismutase (SOD) activity and increases malondialdehyde (MDA) level, leading to oxidative damages on osteoblasts. ${ }^{124}$

The hypolipidemic effect of honey has been demonstrated by Al-Waili (2004). ${ }^{125}$ A significant reduction of total cholesterol (TC) and a decreasing trend of lowdensity lipoprotein cholesterol (LDL) were observed among honey-supplemented patients with dyslipidemia. ${ }^{125}$ In another study, daily $70 \mathrm{~g}$ honey for 1 month also significantly lowered the TG level among dyslipidemic patients by $19 \%$, with similar trends of reduction in TC and LDL, despite the lack of statistical significance. ${ }^{97}$ Similarly, honey also reduced TC, LDL and TG levels, and increased HDL (3.3\%) in non-dyslipidemic individuals, but the changes were statistically not significant. On the other hand, Hemmati et al (2015) reported that honey (1 and $2 \mathrm{~g} / \mathrm{kg}$ for 3 weeks) countered the dyslipidemic effects of streptozotocin by normalizing the TC, TG, HDL, non-HDL levels and atherogenic index (TG/HDL). ${ }^{126}$ Besides, administration of mad honey at the dose of $50 \mathrm{mg} / \mathrm{kg}$ for 3 days significantly reduced TC, TG and very-low-density lipoprotein cholesterol (VLDL) in streptozotocin (STZ)induced diabetic rats. ${ }^{127}$ Mad honey was speculated to act on the parasympathetic nervous system (potentially via M2muscarinic receptors) to increase the lipid metabolism via insulin release. ${ }^{127}$ Another animal study reported that Nigerian honey supplementation for 21 days produced a significant reduction of $\mathrm{TG}$, non-HDL (especially VLDL), cardiovascular risk index (TG/HDL) and coronary risk index (TC/HDL) in rats with alloxan-induced diabetes mellitus (DM). ${ }^{128}$ An RCT Bahrami et al (2009) reported that there was a notable decrease in TC, LDL and TG $(\mathrm{p}=$ 0.000) with increased HDL concentration compared to the baseline level $(\mathrm{p}<0.05)$ in diabetic patients after ingesting honey for 56 days. $^{98}$

A diet containing high fructose induces dyslipidemia and exerts pro-oxidant effects in vivo. ${ }^{129,130}$ Substituting refined carbohydrate with honey ( $650 \mathrm{~g} / \mathrm{kg}$ for 14 days) in the purified diets was reported to reduce TG levels significantly in comparison to fructose-fed rats. ${ }^{131}$ At the same time, honey also reduced the lipid oxidation in the heart, marked by a lower thiobarbituric acid-reactive substance level compared with the fructose-fed group. ${ }^{131}$ Nemoseck et al (2011) also observed that substitution of sucrose in the rat diet with clover honey (with similar energy density) for 33 days resulted in $29.6 \%$ lower TG levels than the sucrose-fed rats. ${ }^{96}$ In another study, metabolic effects of $10 \%$ honeydew honey $(100 \mathrm{~g} / \mathrm{kg})$ mixed in diets were compared with sucrose for 365 days. Although there was no significant decrease in TG and LDL, the honey-fed rats had significantly higher HDL levels than the rats on a sugar-free diet and sucrose diet. ${ }^{132}$ Apolipoprotein $\mathrm{B}$ and TG-rich lipoproteins play a role in developing atherosclerotic cardiovascular disease. ${ }^{133,134}$ Pretreatment with $3 \mathrm{~g} / \mathrm{kg} /$ day of Tualang honey for 45 days in rats with isoproterenol-induced myocardial infarction was shown to normalize cholesterol levels. ${ }^{135}$ Serum TC and TG levels were significantly reduced in rats receiving Tualang honey compared to the untreated disease control group. ${ }^{135}$ Aziz et al (2017) observed similar results, in which STZnicotinamide-induced rats given stingless bee honey $(2.0$ 
$\mathrm{g} / \mathrm{kg}$ for 28 days) showed significant reductions of TC, TG and LDL levels and an increase in HDL level compared to untreated diabetic rats. ${ }^{136}$

Similar to the anti-obesity effect, the underlying mechanism of the hypolipidemic effect of honey remains unclear. Given the hypolipidemic effect of honey, honey could protect the bone against osteoporosis caused by hyperlipidemia. By lowering the blood lipid level, it could reduce lipid oxidation, which is a risk factor of osteoporosis, subsequently preventing bone loss.

\section{Honey and Hyperglycemia}

Diabetic Cohen rats [a non-obese rat model of type $2 \mathrm{DM}$ (T2DM)] demonstrated reduced BMD of distal femur and vertebra compared to normal rats. ${ }^{137}$ Prediabetic individuals with impaired FBG and/or glucose tolerance are positively associated with TNF- $\alpha$ level. ${ }^{138}$ Upregulation of TNF- $\alpha$, macrophage-colony stimulating factor (M-CSF) and RANKL caused suppression of bone formation and deterioration of bone strength in STZ-induced diabetic mice. ${ }^{139}$ Histomorphometric analysis further revealed the increase in osteoclast numbers in conjunction with osteoclastogenic mediator expression in STZ-induced diabetic mice. ${ }^{139}$ On the other hand, STZ-mediated hyperglycemia decreased osteocalcin (a bone formation marker) and Runx 2 mRNAs expression with high PPAR- $\gamma$ expression in the bone marrow. ${ }^{140,141}$ Besides, a previous study demonstrated an increased glomerular filtration rate and urinary calcium, as well as reduced fractional calcium reabsorption in STZ-induced diabetic rats. ${ }^{141}$

The results of human studies are in parallel with animal studies. Subjects with diabetes demonstrated lower hip BMD in diabetic subjects compared to the non-diabetic. Insulin-dependent DM or type $1 \mathrm{DM}$ (T1DM) often affects younger individuals due to its early onset. ${ }^{142}$ Both T1DM and non-insulin-dependent DM or T2DM patients display impaired bone formation, but T1DM patients have a greater fracture risk. ${ }^{143,144}$ Surprisingly, BMD was increased in T2DM but not T1DM. ${ }^{145,146}$ Apparently, the fracture risk in T2DM patients is independent of the BMD. ${ }^{147}$ The underlying reason for this remains unknown. However, conditions like visual disturbance due to diabetic retinopathy and cataract, increased fall risk due to peripheral neuropathy and T2DM treatment may contribute to the fracture risk. ${ }^{147,148}$

Hyperglycemia has direct and indirect detrimental effects on osteoblast function and bone formation. High glucose concentration significantly suppresses mineralization and osteoblastogenesis and increases the adipogenesis and osteoblast apoptosis in MG63 cells. ${ }^{149}$ Insulin and insulin-like growth factor-1 (IGF-1) are humoral factors synthesized by liver and osteoblasts, acting as a vital anabolic signal to promote bone formation. ${ }^{150,151}$ Deficiency of insulin and IGF-1 occurs in T1DM, whereby it has been associated with low BMD, low bone size, growth hindrance, and development of osteoporosis. ${ }^{152-154}$ Renal glycosuria, which is the indirect effect of hyperglycemia, causes defective reabsorption of both glucose and calcium in the proximal tubule or collecting duct, leading to hypercalciuria and depletion of calcium level in the body, thereby resulting in bone loss. ${ }^{155,156}$

Hyperglycemia also impairs fracture healing by reducing endothelial progenitor cells lining the blood vessels, leading to retardation of the angiogenesis process. ${ }^{143}$ This event will hinder the repair process at fracture sites. Decreased BMD and biomechanical strength in DM is negatively correlated with the accumulation of advanced glycation end product (AGE) or non-enzymatic crosslinks within collagen fibers. ${ }^{157,158}$ AGEs enhance bone resorption in cultured mouse unfractionated bone cells and induce the mesenchymal stem cell apoptosis, which eventually leads to bone loss. ${ }^{159,160}$

Hypoglycemic effects of honey have been studied extensively through various animal studies and RCTs. Aziz et al (2017) demonstrated a significant reduction of FBG level in rats with partial insulin deficiency induced by combined STZ-nicotinamide upon treated with stingless bee honey (Kelulut honey; 1.0 and $2.0 \mathrm{~g} / \mathrm{kg} / \mathrm{day}$ for 28 days) compared to the untreated diabetic rats. ${ }^{136}$ Serum insulin level and pancreatic oxidative status were improved, as evidenced by increased CAT expression and faster pancreatic healing process. ${ }^{136}$ The active compound in Kelulut honey, L-phenylalanine was suggested to stimulate insulin release and improve glucose tolerance in diabetic rats. ${ }^{161}$

Besides, treatment with Tualang honey at $1.0 \mathrm{~g} / \mathrm{kg} / \mathrm{day}$ for 28 days significantly downregulated pancreatic MDA level and restored the SOD and CAT activities in STZinduced diabetic rats. ${ }^{162}$ The antioxidant effects of Tualang honey also protected the pancreas from STZmediated oxidative damage, leading to significant improvement of FBG in diabetic rats. ${ }^{162}$ A similar hypoglycemic effect of honey with a significant reduction in FBG was demonstrated on alloxan-induced diabetic rats upon supplementation of Nigerian honey at 1.0 and $2.0 \mathrm{~g} /$ $\mathrm{kg} /$ day for 21 days. ${ }^{128}$ Additionally, histological analysis 
in rats also revealed that honey increased pancreatic $\beta$ cells which explains its hypoglycemic effects. ${ }^{163}$

The hypoglycemic effects of honey were replicated in human studies. Unprocessed honey was given orally to 25 T2DM patients at the starting dose of $1.0 \mathrm{~g} / \mathrm{kg} / \mathrm{day}$ and gradually increased by $0.5 \mathrm{~g} / \mathrm{kg} /$ day every 14 days for a total duration of 56 days. Patients receiving honey experienced a significant reduction of FBG level at the end of treatment than the starting baseline level. ${ }^{98}$ In another study, 7 T2DM patients were given honey solution ( $90 \mathrm{~g}$ of honey dissolved in $250 \mathrm{~mL}$ of water for 8 weeks) as a substitute for dextrose $30 \mathrm{~min}$ before blood sampling for oral glucose tolerance test. ${ }^{98}$ The honey-supplemented subjects showed significantly lower blood glucose elevation. ${ }^{98,107}$ This finding suggests that substituting honey for sugar might be useful in the management of diabetes if taken in moderate quantities. ${ }^{131,164,165}$

Mechanistically, honey could lower blood glucose by inhibiting $\alpha$-amylase and $\alpha$-glucosidase activities. ${ }^{166}$ Alpha-amylase is an enzyme responsible for the hydrolysis of complex starch to oligosaccharides, whereas $\alpha$ glucosidase hydrolyses oligosaccharides, trisaccharides and disaccharides into monosaccharides. Postprandial blood glucose levels can be reduced through the reduction in polysaccharides breakdown and digestion upon the inhibition of these enzymes. ${ }^{167-169}$ Krishnasree \& Ukkuru (2017) analyzed the antidiabetic activity of honey using in vitro $\alpha$-amylase and $\alpha$-glucosidase enzyme inhibition assays. ${ }^{166}$ Trigona iridipennis honey, a type of stingless bee honey, demonstrated the strongest $\alpha$-amylase and $\alpha$ glucosidase inhibitory properties than other multifloral honey species. ${ }^{166}$ This was comparable to standard diabetic therapy by acarbose, especially at the highest honey concentration of $500 \mu \mathrm{g} / \mathrm{mL} .{ }^{166}$ Furthermore, raw T. iridipennis honey had the lowest glycemic index (GI) of 55, making it a suitable sweetener for diabetic patients. ${ }^{166}$

Overall, honey could reduce the blood glucose level through the inhibition of $\alpha$-amylase and $\alpha$-glucosidase activities and its antioxidant activities. Hence, honey could prevent hyperglycemia and its adverse effects on bone in MetS patients.

\section{Honey and Hypertension}

Hypertension, a multifactorial disease, is one of the components of MetS. Blood pressure is regulated by controlling the diameter of blood vessels through the autonomic nervous system via vasodilation and vasoconstrictions. ${ }^{170}$ Sympathetic nervous system activation leads to vasoconstriction, increased cardiac output and sodium retention by renal tubule that leads to an increase in blood pressure. ${ }^{171}$ Besides, obesity is one of the significant factors contributing to hypertension. ${ }^{172}$ Obesity is associated with hypertension due to the secretion of leptin by adipocytes, which has been reported to stimulate the sympathetic nervous system. ${ }^{173}$ Additionally, diets high in fructose, sucrose and fat have been observed to increase blood pressure and obesity simultaneously. ${ }^{174,175}$

Renal and vascular oxidative stress also contributes to the development of hypertension. ${ }^{176-178}$ Oxidative stress causes inflammation of the vascular wall, reduced bioavailability of vasodilatory agent (NO), extracellular matrix alterations as well as increased vascular cell proliferation. ${ }^{177}$ Long-term exposure to ROS, especially to hydrogen peroxide, inhibits the antioxidant response due to down-regulation of the Akt and impaired nuclear translocation of nuclear factor erythroid 2-related factor 2 (Nrf2) signaling pathway. ${ }^{179}$

A significant positive relationship between hypertension and bone loss has been suggested. At the same age, spontaneous hypertensive rats (SHR) had lower BMD and bone magnesium content than normotensive Wistar-Kyoto (WKY) rats. ${ }^{180}$ Furthermore, SHR exhibited disturbed bone healing with a lower percentage of the trabecular bone area and newly formed bone area compared to WKY rats. ${ }^{181}$ Administration of $2 \%$ calcium diet (but not $1 \%$ ) could significantly normalize the BMD of SHR. ${ }^{180}$ The BMD of WKY rats was increased by both 1 and 2\% calcium diet. ${ }^{180}$ This indicates the involvement of calcium loss in hypertension-related bone loss where it could be corrected by optimal calcium supplementation.

Human studies have indicated that hypertension is negatively correlated with BMD. ${ }^{182,183}$ Cappuccio et al found that hypertension was associated with increased bone loss at the femoral neck among 34 Caucasian women. ${ }^{182}$ A longitudinal study by Yang et al found that women ( $\mathrm{n}=1701)$ with hypertension had lower BMD at the femoral neck than those without hypertension. ${ }^{183}$ A meta-analysis by Ye et al also revealed that essential hypertension caused a significant reduction in BMD of the human body, including the lumbar spine, femoral neck, Ward's triangle, femoral intertrochanteric region, calcaneus and distal forearm. ${ }^{184}$ Parallelly, Gotoh et al (2005) also demonstrated that the BMD of hypertensive patients was significantly lower than that of normal controls, where BMD was negatively correlated with systolic blood pressure. ${ }^{185}$ Therefore, essential hypertension might be a risk factor for low BMD. ${ }^{185}$ 
Mechanically, osteoporosis and hypertension share similar etiopathology with interactions of genetic and environmental factors. Both diseases are associated with calcium, vitamin $\mathrm{D}$ and vitamin $\mathrm{K}$ deficiency, high sodium consumption, and low or very high NO levels. Calcium, the main bone mineral, has a significant impact on bone strength and the balance of the bone remodeling process. ${ }^{186}$ The significance of calcium metabolism in hypertension and osteoporosis has been reported. ${ }^{186}$ Hypertension reduced intestinal absorption of calcium as well as increased calcium urinary elimination. ${ }^{187}$ This reduces calcium concentration in the plasma, leading to secondary activation of parathyroid glands and calcium mobilization from the bone into the circulation, resulting in increased bone turnover. ${ }^{182,188,189}$

Honey is beneficial in preventing hypertension through its antioxidant and anti-inflammatory effects. Tualang honey supplementation in SHR at $1 \mathrm{~g} / \mathrm{kg} /$ day for 12 weeks attenuated renal oxidative stress. ${ }^{190}$ It upregulated mRNA, protein expression and nuclear translocation of $\mathrm{Nrf2}$, thus augmenting gene expression of antioxidation enzymes such as CAT and glutathione-S-transferase (GST). ${ }^{190}$ Ultimately, the upregulation of these enzymes reduced the oxidative damages in the kidney, restored renal function and subsequently reduced the blood pressure. ${ }^{174,190}$ Similarly, the antioxidative properties of Tualang honey were also effective in reducing blood pressure in STZ-induced diabetic SHR. ${ }^{191}$ In human studies, administration of $60 \%$ honey solution via inhalational route resulted in a marked decrease in blood pressure at 60 and 120 min post-treatment in hypertensive subjects, which indicates immediate blood pressure-lowering effects. ${ }^{192}$ Similar instant hypotensive effects of honey have been reported in healthy subjects. ${ }^{193,194}$ The underlying mechanism of action of honey in reducing blood pressure is unknown. Honey contains a high concentration of NO, which may contribute to its therapeutic effects on hypertension. ${ }^{192}$ Ultimately, the antihypertensive effects of honey could benefit both the cardiovascular and bone health of the patients.

\section{Honey and Skeletal Health}

Honey exhibits both antioxidative properties and possesses anti-inflammatory effects, which could be directly beneficial to bone health. Previous studies have shown that honey reduced $\mathrm{PGE}_{2}$ level and inhibited NO production in rats. ${ }^{195}$ Zaid et al reported that two-week consumption of Tualang honey $(0.2 \mathrm{~g} / \mathrm{kg} /$ day $)$ could increase bone density in female ovariectomized rats, comparable to those of control intact rats. ${ }^{196}$ Another study performed by Lily et al showed that the daily intake of Tualang honey at $20 \mathrm{mg} /$ day for 4 months to postmenopausal women was safe and exerted the same effect on bone densitometry when compared to hormone replacement therapy. ${ }^{197}$ These positive effects of Tualang honey on bone are probably due to its anti-inflammatory property, antioxidative property, and calcium and gluconic acid content. ${ }^{198}$

A recent study found that Kelulut honey at $400 \mathrm{mg} / \mathrm{kg}$ reversed the changes in the femoral bones of rats receiving long-term dexamethasone. ${ }^{199}$ Bone structural parameters and osteoblast number in the Kelulut honey treated-group were preserved with a lower osteoclast number compared to the non-treated osteoporotic group. ${ }^{199}$ Kelulut honey also reduced the MDA level and augmented SOD activity in dexamethasone-mediated osteoporotic rats. ${ }^{199}$ This observation implies that the antioxidant properties of the honey can prevent osteoblast apoptosis by oxidative stress. ${ }^{199,200}$

Several phenolic compounds in honey have been reported contributing to the bone protective effects of honey. Honey contains polyphenols with antioxidant potential, which can increase the differentiation of mesenchymal cells to osteoblasts. ${ }^{199-202}$ They also play a role in the cross-talk of signaling pathways, such as Wnt and BMPs, thus promoting mesenchymal cell differentiation to osteoblasts. ${ }^{203}$ Flavanols, such as quercetin and kaempferol, could affect bone resorption by directly introducing osteoclasts apoptosis, thus reducing their numbers and bone resorption. ${ }^{204}$ They decrease the intracellular ROS in osteoclasts and interact with estrogen receptors in the cells. ${ }^{204}$ Parallelly, Trivedi et al also found that kaempferol promotes osteoblast function, thus preventing ovariectomized-induced bone loss. ${ }^{195}$ Gluconic acid, a major constituent in honey, could enhance calcium absorption in the bone, consequently maintaining bone mass and preventing osteoporosis. ${ }^{205}$ It is a major organic acid in honey produced through enzymatic glucose oxidase reaction. In the digestive tract, gluconic acid is then fermented by lactic acid bacteria (Lactobacillus reuteri and L. mucosae) to produce lactate and acetate, and eventually convert into butyrate by acid-utilizing bacteria (Megasphaera elsdenii and Mitsuokella multiacida). ${ }^{206,207}$ Butyrate is a type of short-chain fatty acid rapidly absorbed by the mucosa of the large intestine. It is reported to have hypoglycemic, antioxidant and antiinflammatory properties in maintaining gut health and 


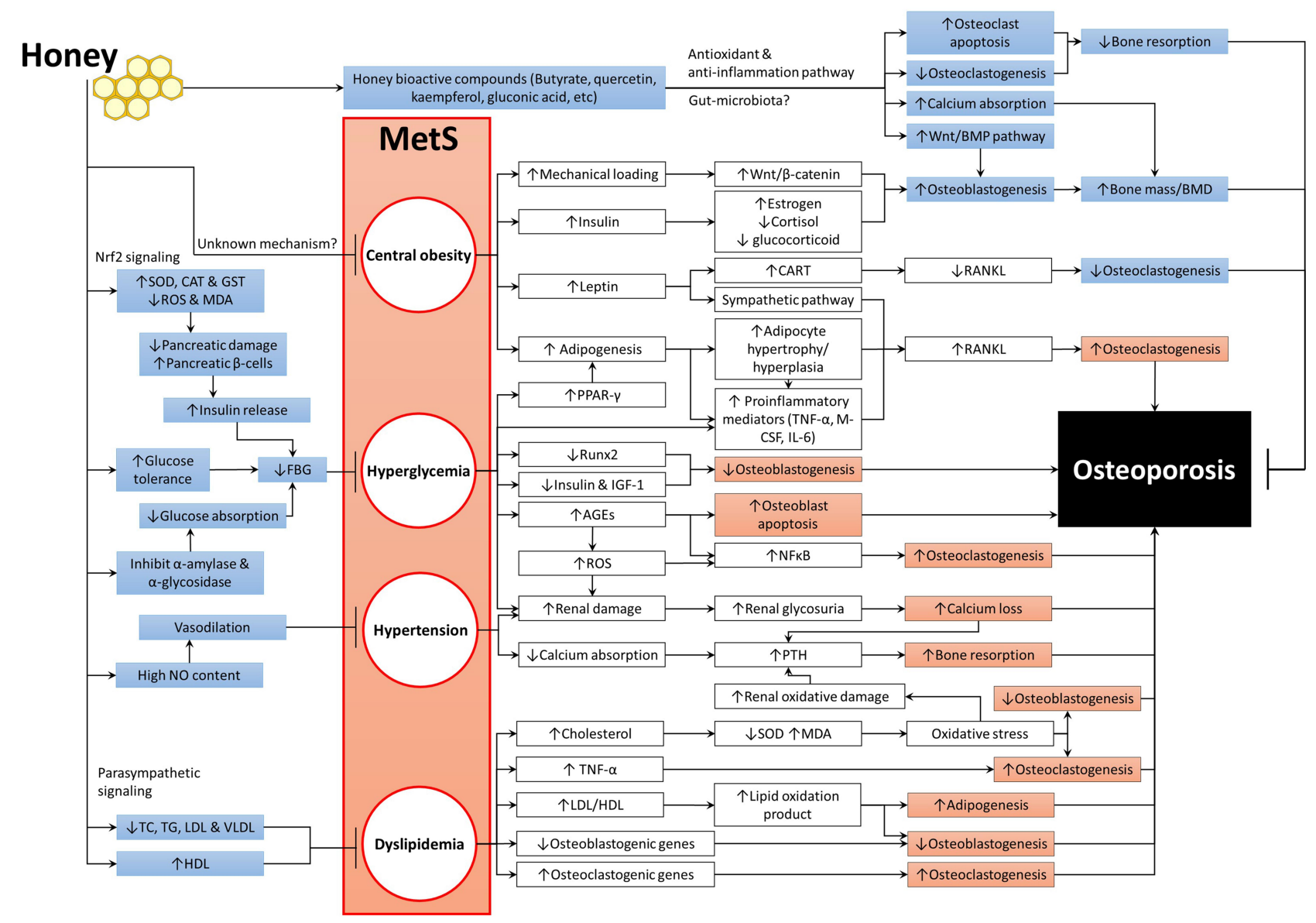

Figure I The beneficial effects of honey on MetS and bone health.

Abbreviations: $\uparrow$, increase or upregulate; $\downarrow$, decrease or downregulate; $\rightarrow$, promote or induce; $T$, inhibit or prevent; AGEs, advanced glycation end products; BMPs, bone morphogenetic proteins; CART, cocaine amphetamine-regulated transcript; CAT, catalase; FBG, fasting blood glucose; GST, glutathione-S-transferase; HDL, high-density lipoprotein; LDL, low-density lipoprotein; IGF-I, insulin-like growth factor-I; IL-6, interleukin-6; M-CSF, macrophage-colony stimulating factor; MDA, malondialdehyde; MetS, metabolic syndrome; $\mathrm{NF}-\mathrm{kB}$, nuclear factor kappa-B; NO, nitric oxide; PPAR- $\gamma$, peroxisome proliferator-activated receptor-gamma; PTH, parathyroid hormone; RANKL, receptor activator of nuclear factor kappa-B ligand; ROS, reactive oxygen species; Runx-2, Runt-related transcription factor 2; SOD, superoxide dismutase; TC, total cholesterol; TG, triglyceride; TNF- $\alpha$, tumour necrosis factor-alpha; VLDL, very-low-density lipoprotein.

regulating energy metabolism. ${ }^{208-211}$ Additionally, butyrate is also being postulated as the linkage between gut microbiota and bone health. ${ }^{212-214}$

\section{Conclusions}

Understanding the association between MetS and osteoporosis and its mechanisms will help developing therapeutic intervention effective for both diseases. Honey exhibits protective effects against MetS by exerting anti-obesity, antidiabetic, hypolipidemic and hypotensive activities. It has a low GI, which can limit weight gain and prevent the accumulation of fat, thus improves insulin sensitivities and reduces blood glucose levels. Honey can enhance energy and lipid metabolism, which will prevent atherogenesis and attenuate oxidative stress and endothelial dysfunction. The improvement of MetS caused by honey could, in turn, prevent bone loss. Figure 1 summarizes the mechanisms of MetS in inducing osteoporosis and the beneficial effects of honey on both MetS and bone health. The antiinflammatory of honey plays a major role in mediating these biological activities. Therefore, honey has a strong potential to be utilized in the management of MetS and osteoporosis associated with it.

\section{Acknowledgments}

The authors thank the Ministry of Education, Malaysia for funding the researchers through FRGS/1/2019/SKK06/ $\mathrm{UKM} / 03 / 2$.

\section{Disclosure}

The authors report no conflicts of interest in this work. 


\section{References}

1. Alberti KG, Eckel RH, Grundy SM, et al. Harmonizing the metabolic syndrome: a joint interim statement of the international diabetes federation task force on epidemiology and prevention; national heart, lung, and blood institute; American heart association; world heart federation; international atherosclerosis society; and international association for the study of obesity. Circulation. 2009;120 (16):1640-1645. doi:10.1161/CIRCULATIONAHA.109.192644

2. Kolovou GD, Anagnostopoulou KK, Salpea KD, Mikhailidis DP. The prevalence of metabolic syndrome in various populations. Am J Med Sci. 2007;333(6):362-371. doi:10.1097/MAJ.0b013e318065c3a1

3. Desroches S, Lamarche B. The evolving definitions and increasing prevalence of the metabolic syndrome. Appl Physiol Nutr Metab. 2007;32(1):23-32. doi:10.1139/h06-095

4. Ranasinghe P, Mathangasinghe Y, Jayawardena R, Hills AP, Misra A. Prevalence and trends of metabolic syndrome among adults in the asia-pacific region: a systematic review. BMC Public Health. 2017;17(1):101. doi:10.1186/s12889-017-4041-1

5. Kaur J. A comprehensive review on metabolic syndrome. Cardiol Res Pract. 2014;2014:943162. doi:10.1155/2014/943162

6. Grundy SM. Drug therapy of the metabolic syndrome: minimizing the emerging crisis in polypharmacy. Nat Rev Drug Discov. 2006;5(4):295-309. doi:10.1038/nrd2005

7. Nestel P, Lyu R, Low LP, et al. Metabolic syndrome: recent prevalence in east and southeast Asian populations. Asia Pac J Clin Nutr. 2007;16(2):362-367.

8. Pan WH, Yeh WT, Weng LC. Epidemiology of metabolic syndrome in Asia. Asia Pac J Clin Nutr. 2008;17(Suppl 1):37-42.

9. Xu H, Li X, Adams H, Kubena K, Guo S. Etiology of metabolic syndrome and dietary intervention. Int J Mol Sci. 2018;20(1):128. doi:10.3390/ijms20010128

10. Lear SA, Gasevic D. Ethnicity and metabolic syndrome: implications for assessment, management and prevention. Nutrients. 2019;12(1):15. doi:10.3390/nu12010015

11. Kuk JL, Ardern CI. Age and sex differences in the clustering of metabolic syndrome factors: association with mortality risk. Diabetes Care. 2010;33(11):2457-2461. doi:10.2337/dc10-0942

12. Moore JX, Chaudhary N, Akinyemiju T. Metabolic syndrome prevalence by race/ethnicity and sex in the United States, national health and nutrition examination survey, 1988-2012. Prev Chronic Dis. 2017;14:E24. doi:10.5888/pcd14.160287

13. Rask Larsen J, Dima L, Correll CU, Manu P. The pharmacological management of metabolic syndrome. Expert Rev Clin Pharmacol. 2018;11(4):397-410. doi:10.1080/17512433.2018.1429910

14. van Zwieten PA, Visser FC. Metabolic syndrome: pharmacological treatment. Heart Metab. 2006;30:15-20.

15. Lupachyk S, Watcho P, Obrosov AA, Stavniichuk R, Obrosova IG. Endoplasmic reticulum stress contributes to prediabetic peripheral neuropathy. Exp Neurol. 2013;247:342-348. doi:10.1016/j.expneurol.2012.11.001

16. Odegaard JI, Chawla A. Pleiotropic actions of insulin resistance and inflammation in metabolic homeostasis. Science. 2013;339 (6116):172-177. doi:10.1126/science.1230721

17. Nishimura S, Manabe I, Nagai R. Adipose tissue inflammation in obesity and metabolic syndrome. Discov Med. 2009;8(41):55-60.

18. Olefsky JM, Glass CK. Macrophages, inflammation, and insulin resistance. Annu Rev Physiol. 2010;72(1):219-246. doi:10.1146/ annurev-physiol-021909-135846

19. Patel S, Santani D. Role of NF-kappa B in the pathogenesis of diabetes and its associated complications. Pharmacol Rep. 2009;61(4):595-603. doi:10.1016/S1734-1140(09)70111-2

20. Aschbacher K, Rodriguez-Fernandez M, van Wietmarschen H, et al. The hypothalamic-pituitary-adrenal-leptin axis and metabolic health: a systems approach to resilience, robustness and control. Interface Focus. 2014;4(5):20140020. doi:10.1098/rsfs.2014.0020
21. McCall AL. Altered glycemia and brain-update and potential relevance to the aging brain. Neurobiol Aging. 2005;26(Suppl 1):70-75. doi:10.1016/j.neurobiolaging.2005.08.009

22. Carroll BJ, Cassidy F, Naftolowitz D, et al. Pathophysiology of hypercortisolism in depression. Acta Psychiatr Scand Suppl. 2007;(433):90-103. doi:10.1111/j.1600-0447.2007.00967.x

23. Ng J-S, Chin K-Y. Potential mechanisms linking psychological stress to bone health. Int $J$ Med Sci. 2021;18(3):604-614. doi:10.7150/ijms.50680

24. Kanis JA, Melton LJ 3rd, Christiansen C, Johnston CC, Khaltaev N. The diagnosis of osteoporosis. J Bone Miner Res. 1994;9(8):1137-1141. doi:10.1002/jbmr.5650090802

25. World Health Organization. Assessment of Fracture Risk and Its Application to Screening for Postmenopausal Osteoporosis: Report of a World Health Organization Study Group. Geneva: World Health Organization; 1994.

26. Sandhu SK, Hampson G. The pathogenesis, diagnosis, investigation and management of osteoporosis. J Clin Pathol. 2011;64 (12):1042-1050. doi:10.1136/jcp.2010.077842

27. Muka T, Trajanoska K, Kiefte-de Jong JC, et al. The association between metabolic syndrome, bone mineral density, hip bone geometry and fracture risk: the rotterdam study. PLoS One. 2015;10(6):e0129116. doi:10.1371/journal.pone.0129116

28. Chin K-Y, Wong SK, Ekeuku SO, Pang K-L. Relationship between metabolic syndrome and bone health - an evaluation of epidemiological studies and mechanisms involved. Diabetes Metab Syndr Obes. 2020;13:3667-3690. doi:10.2147/DMSO. S275560

29. Wong SK, Chin K-Y, Suhaimi F, Ahmad F, Ima-Nirwana S. The relationship between metabolic syndrome and osteoporosis: a review. Nutrients. 2016;8(6):347. doi:10.3390/nu8060347

30. Zhou J, Zhang Q, Yuan X, et al. Association between metabolic syndrome and osteoporosis: a meta-analysis. Bone. 2013;57 (1):30-35. doi:10.1016/j.bone.2013.07.013

31. Reddy P, Lent-Schochet D, Ramakrishnan N, McLaughlin M, Jialal I. Metabolic syndrome is an inflammatory disorder: a conspiracy between adipose tissue and phagocytes. Clin Chim Acta. 2019;496:35-44. doi:10.1016/j.cca.2019.06.019

32. Hadagali MD, Chua LS. The anti-inflammatory and wound healing properties of honey. Eur Food Res Technol. 2014;239 (6):1003-1014. doi:10.1007/s00217-014-2297-6

33. Mueller M, Hobiger S, Jungbauer A. Anti-inflammatory activity of extracts from fruits, herbs and spices. Food Chem. 2010;122 (4):987-996. doi:10.1016/j.foodchem.2010.03.041

34. Mirończuk-Chodakowska I, Witkowska AM, Zujko ME. Endogenous non-enzymatic antioxidants in the human body. $A d v$ Med Sci. 2018;63(1):68-78. doi:10.1016/j.advms.2017.05.005

35. Rao LG, Rao AV. Oxidative stress and antioxidants in the risk of osteoporosis - role of the antioxidants lycopene and polyphenols. In: Flores MV, editor. Topics in Osteoporosis. London: IntechOpen; 2013.

36. Dias TR, Bernardino RL, Meneses MJ, et al. Emerging potential of natural products as an alternative strategy to pharmacological agents used against metabolic disorders. Curr Drug Metab. 2016;17(6):582-597. doi:10.2174/1389200217666160229113629

37. Kamaruzzaman MA, Chin K-Y, Mohd Ramli ES. A review of potential beneficial effects of honey on bone health. Evid Based Complement Alternat Med. 2019;2019:8543618. doi:10.1155/ 2019/8543618

38. Alvarez-Suarez JM, Tulipani S, Romandini S, Bertoli E, Battino M. Contribution of honey in nutrition and human health: a review. Med J Nutrition Metab. 2010;3(1):15-23. doi:10.1007/ s12349-009-0051-6

39. da Silva PM, Gauche C, Gonzaga LV, Costa AC, Fett R. Honey: chemical composition, stability and authenticity. Food Chem. 2016;196:309-323. doi:10.1016/j.foodchem.2015.09.051 
40. Cianciosi D, Forbes-Hernández TY, Afrin S, et al. Phenolic compounds in honey and their associated health benefits: a review. Molecules. 2018;23(9):2322. doi:10.3390/molecules23092322

41. Eteraf-Oskouei T, Najafi M. Traditional and modern uses of natural honey in human diseases: a review. Iran J Basic Med Sci. 2013;16(6):731-742.

42. Ahmed S, Sulaiman SA, Baig AA, et al. Honey as a potential natural antioxidant medicine: an insight into its molecular mechanisms of action. Oxid Med Cell Longev. 2018;2018:8367846. doi:10.1155/2018/8367846

43. Kassim M, Achoui M, Mustafa MR, Mohd MA, Yusoff KM. Ellagic acid, phenolic acids, and flavonoids in Malaysian honey extracts demonstrate in vitro anti-inflammatory activity. Nutr Res. 2010;30(9):650-659. doi:10.1016/j.nutres.2010.08.008

44. Hussein SZ, Mohd Yusoff K, Makpol S, Mohd Yusof YA. Gelam honey inhibits the production of proinflammatory, mediators NO, PGE(2), TNF-alpha, and IL-6 in carrageenan-induced acute paw edema in rats. Evid Based Complement Alternat Med. 2012;2012:109636. doi:10.1155/2012/109636

45. Owoyele BV, Adenekan OT, Soladoye AO. Effects of honey on inflammation and nitric oxide production in Wistar rats. Zhong $X i$ Yi Jie He Xue Bao. 2011;9(4):447-452. doi:10.3736/jcim20110415

46. Afroz R, Tanvir EM, Paul S, Bhoumik NC, Gan SH, Khalil MDI. DNA damage inhibition properties of sundarban honey and its phenolic composition. J Food Biochem. 2016;40(4):436-445. doi: $10.1111 / \mathrm{jfbc} .12240$

47. Hussein SZ, Mohd Yusoff K, Makpol S, Mohd Yusof YA. Gelam honey attenuates carrageenan-induced rat paw inflammation via NF-kappaB pathway. PLoS One. 2013;8(8):e72365. doi:10.1371/ journal.pone.0072365

48. BenSaad LA, Kim KH, Quah CC, Kim WR, Shahimi M. Antiinflammatory potential of ellagic acid, gallic acid and punicalagin $\mathrm{A} \& \mathrm{~B}$ isolated from Punica granatum. BMC Complement Altern Med. 2017;17(1):47. doi:10.1186/s12906-017-1555-0

49. Choi KC, Lee YH, Jung MG, et al. Gallic acid suppresses lipopolysaccharide-induced nuclear factor-kappaB signaling by preventing RelA acetylation in A549 lung cancer cells. Mol Cancer Res. 2009;7(12):2011-2021. doi:10.1158/1541-7786. MCR-09-0239

50. Mavric E, Wittmann S, Barth G, Henle T. Identification and quantification of methylglyoxal as the dominant antibacterial constituent of Manuka (Leptospermum scoparium) honeys from New Zealand. Mol Nutr Food Res. 2008;52(4):483-489. doi:10.1002/mnfr.200700282

51. Forbes-Hernández TY, Giampieri F, Gasparrini M, et al. The effects of bioactive compounds from plant foods on mitochondrial function: a focus on apoptotic mechanisms. Food Chem Toxicol. 2014;68:154-182. doi:10.1016/j.fct.2014.03.017

52. Fukuda M, Kobayashi K, Hirono Y, et al. Jungle honey enhances immune function and antitumor activity. Evid Based Complement Alternat Med. 2011;2011:908743. doi:10.1093/ecam/nen086

53. Ghashm AA, Othman NH, Khattak MN, Ismail NM, Saini R. Antiproliferative effect of Tualang honey on oral squamous cell carcinoma and osteosarcoma cell lines. BMC Complement Altern Med. 2010;10(1):49. doi:10.1186/1472-6882-10-49

54. Swellam T, Miyanaga N, Onozawa M, et al. Antineoplastic activity of honey in an experimental bladder cancer implantation model: in vivo and in vitro studies. Int $J$ Urol. 2003;10 (4):213-219. doi:10.1046/j.0919-8172.2003.00602.x

55. World Health Organization. Obesity: Preventing and Managing the Global Epidemic. Geneva: World Health Organization; 2003.

56. Ashwell M, Gunn P, Gibson S. Waist-to-height ratio is a better screening tool than waist circumference and BMI for adult cardiometabolic risk factors: systematic review and meta-analysis. Obes Rev. 2012;13(3):275-286. doi:10.1111/ j.1467-789X.2011.00952.x
57. Kopelman PG. Obesity as a medical problem. Nature. 2000;404 (6778):635-643. doi:10.1038/35007508

58. Reid IR, Ames R, Evans MC, et al. Determinants of total body and regional bone mineral density in normal postmenopausal women-a key role for fat mass. J Clin Endocrinol Metab. 1992;75(1):45-51. doi:10.1210/jcem.75.1.1619030

59. Villareal DT, Apovian CM, Kushner RF, Klein S. American society for $\mathrm{N}$, naaso TOS. obesity in older adults: technical review and position statement of the American society for nutrition and NAASO, the obesity society. Am J Clin Nutr. 2005;82 (5):923-934. doi:10.1093/ajcn/82.5.923

60. Bonewald LF, Johnson ML. Osteocytes, mechanosensing and Wnt signaling. Bone. 2008;42(4):606-615. doi:10.1016/j. bone.2007.12.224

61. Sawakami K, Robling AG, Ai M, et al. The Wnt co-receptor LRP5 is essential for skeletal mechanotransduction but not for the anabolic bone response to parathyroid hormone treatment. J Biol Chem. 2006;281(33):23698-23711. doi:10.1074/jbc.M601000200

62. Ehrlich PJ, Lanyon LE. Mechanical strain and bone cell function: a review. Osteoporos Int. 2002;13(9):688-700. doi:10.1007/ s001980200095

63. Wilcox G. Insulin and insulin resistance. Clin Biochem Rev. 2005;26(2):19-39.

64. Reid IR. Relationships among body mass, its components, and bone. Bone. 2002;31(5):547-555.

65. Goulding A, Taylor RW, Jones IE, McAuley KA, Manning PJ, Williams SM. Overweight and obese children have low bone mass and area for their weight. Int J Obes Relat Metab Disord. 2000;24(5):627-632. doi:10.1038/sj.ijo.0801207

66. Blum M, Harris SS, Must A, et al. Leptin, body composition and bone mineral density in premenopausal women. Calcif Tissue Int. 2003;73(1):27-32. doi:10.1007/s00223-002-1019-4

67. Hsu YH, Venners SA, Terwedow HA, et al. Relation of body composition, fat mass, and serum lipids to osteoporotic fractures and bone mineral density in Chinese men and women. Am J Clin Nutr. 2006;83(1):146-154. doi:10.1093/ajen/83.1.146

68. Pollock NK, Laing EM, Baile CA, Hamrick MW, Hall DB, Lewis RD. Is adiposity advantageous for bone strength? A peripheral quantitative computed tomography study in late adolescent females. Am J Clin Nutr. 2007;86(5):1530-1538. doi:10.1093/ajcn/86.5.1530

69. Fujita Y, Maki K. High-fat diet-induced obesity triggers alveolar bone loss and spontaneous periodontal disease in growing mice. BMC Obes. 2015;3(1):1. doi:10.1186/s40608-016-0082-8

70. Cao J, Gregoire B, Gao H. High-fat diet decreases cancellous bone mass but has no effect on cortical bone mass in the tibia in mice. Bone. 2009;44(6):1097-1104. doi:10.1016/j.bone.2009.02.017

71. Xu F, Du Y, Hang S, Chen A, Guo F, Xu T. Adipocytes regulate the bone marrow microenvironment in a mouse model of obesity. Mol Med Rep. 2013;8(3):823-828. doi:10.3892/mmr.2013.1572

72. Gregoire FM, Smas CM, Sul HS. Understanding adipocyte differentiation. Physiol Rev. 1998;78(3):783-809. doi:10.1152/ physrev.1998.78.3.783

73. Gimble JM, Robinson $\mathrm{CE}, \mathrm{Wu} \mathrm{X}$, et al. Peroxisome proliferator-activated receptor-gamma activation by thiazolidinediones induces adipogenesis in bone marrow stromal cells. Mol Pharmacol. 1996;50(5):1087-1094.

74. David V, Martin A, Lafage-Proust MH, et al. Mechanical loading down-regulates peroxisome proliferator-activated receptor gamma in bone marrow stromal cells and favors osteoblastogenesis at the expense of adipogenesis. Endocrinology. 2007;148 (5):2553-2562. doi:10.1210/en.2006-1704

75. Sen B, Xie Z, Case N, Ma M, Rubin C, Rubin J. Mechanical strain inhibits adipogenesis in mesenchymal stem cells by stimulating a durable beta-catenin signal. Endocrinology. 2008;149 (12):6065-6075. doi:10.1210/en.2008-0687 
76. Beresford JN, Bennett JH, Devlin C, Leboy PS, Owen ME. Evidence for an inverse relationship between the differentiation of adipocytic and osteogenic cells in rat marrow stromal cell cultures. J Cell Sci. 1992;102(Pt 2):341-351.

77. Moerman EJ, Teng K, Lipschitz DA, Lecka-Czernik B. Aging activates adipogenic and suppresses osteogenic programs in mesenchymal marrow stroma/stem cells: the role of PPAR-gamma2 transcription factor and TGF-beta/BMP signaling pathways. Aging Cell. 2004;3(6):379-389. doi:10.1111/j.14749728.2004.00127.x

78. Meunier P, Aaron J, Edouard C, Vignon G. Osteoporosis and the replacement of cell populations of the marrow by adipose tissue. A quantitative study of 84 iliac bone biopsies. Clin Orthop Relat Res. 1971;80:147-154. doi:10.1097/00003086-197110000-00021

79. Marqués-Iturria I, Pueyo R, Garolera M, et al. Frontal cortical thinning and subcortical volume reductions in early adulthood obesity. Psychiatry Res. 2013;214(2):109-115. doi:10.1016/j. pscychresns.2013.06.004

80. Muir LA, Neeley CK, Meyer KA, et al. Adipose tissue fibrosis, hypertrophy, and hyperplasia: correlations with diabetes in human obesity. Obesity (Silver Spring). 2016;24(3):597-605. doi:10.1002/oby.21377

81. Jo J, Gavrilova O, Pack S, et al. Hypertrophy and/or hyperplasia: dynamics of adipose tissue growth. PLoS Comput Biol. 2009;5 (3):e1000324-e1000324. doi:10.1371/journal.pcbi.1000324

82. Khosla S. Minireview: the OPG/RANKL/RANK system. Endocrinology. 2001;142(12):5050-5055. doi:10.1210/ endo.142.12.8536

83. Pfeilschifter J, Koditz R, Pfohl M, Schatz H. Changes in proinflammatory cytokine activity after menopause. Endocr Rev. 2002;23(1):90-119.

84. Hukshorn CJ, Saris WH. Leptin and energy expenditure. Curr Opin Clin Nutr Metab Care. 2004;7(6):629-633. doi:10.1097/ 00075197-200411000-00007

85. Qi Y, Takahashi N, Hileman SM, et al. Adiponectin acts in the brain to decrease body weight. Nat Med. 2004;10(5):524-529. doi: $10.1038 / \mathrm{nm} 1029$

86. Yamauchi T, Kamon J, Waki H, et al. The fat-derived hormone adiponectin reverses insulin resistance associated with both lipoatrophy and obesity. Nat Med. 2001;7(8):941-946. doi:10.1038/90984

87. Iwamoto I, Fujino T, Douchi T. The leptin receptor in human osteoblasts and the direct effect of leptin on bone metabolism. Gynecol Endocrinol. 2004;19(2):97-104. doi:10.1080/ 09513590412331284389

88. Lin YY, Chen CY, Chuang TY, et al. Adiponectin receptor 1 regulates bone formation and osteoblast differentiation by GSK-3beta/beta-catenin signaling in mice. Bone. 2014;64:147-154. doi:10.1016/j.bone.2014.03.051

89. Vianna AGD, Sanches CP, Barreto FC. Review article: effects of type 2 diabetes therapies on bone metabolism. Diabetol Metab Syndr. 2017;9(1):75. doi:10.1186/s13098-017-0274-5

90. Upadhyay J, Farr OM, Mantzoros CS. The role of leptin in regulating bone metabolism. Metabolism. 2015;64(1):105-113. doi:10.1016/j.metabol.2014.10.021

91. Ducy P, Amling M, Takeda S, et al. Leptin inhibits bone formation through a hypothalamic relay: a central control of bone mass. Cell. 2000;100(2):197-207. doi:10.1016/S0092-8674(00)81558-5

92. Iwase S, Nishimura N, Mano T. Osteoporosis in spaceflight. In: Flores MV, editor. Topics in Osteoporosis. London: IntechOpen; 2013.

93. Takeda S, Elefteriou F, Levasseur R, et al. Leptin regulates bone formation via the sympathetic nervous system. Cell. 2002;111 (3):305-317. doi:10.1016/S0092-8674(02)01049-8

94. Elefteriou F, Ahn JD, Takeda S, et al. Leptin regulation of bone resorption by the sympathetic nervous system and CART. Nature. 2005;434(7032):514-520. doi:10.1038/nature03398
95. Chepulis LM. The effect of honey compared to sucrose, mixed sugars, and a sugar-free diet on weight gain in young rats. $J$ Food Sci. 2007;72(3):S224-229. doi:10.1111/j.1750-3841.2007.00286.x

96. Nemoseck TM, Carmody EG, Furchner-Evanson A, et al. Honey promotes lower weight gain, adiposity, and triglycerides than sucrose in rats. Nutr Res. 2011;31(1):55-60. doi:10.1016/j. nutres.2010.11.002

97. Yaghoobi N, Al-Waili N, Ghayour-Mobarhan M, et al. Natural honey and cardiovascular risk factors; effects on blood glucose, cholesterol, triacylglycerol, CRP, and body weight compared with sucrose. Sci World J. 2008;8:463-469. doi:10.1100/tsw.2008.64

98. Bahrami M, Ataie-Jafari A, Hosseini S, Foruzanfar MH, Rahmani M, Pajouhi M. Effects of natural honey consumption in diabetic patients: an 8-week randomized clinical trial. Int $J$ Food Sci Nutr. 2009;60(7):618-626. doi:10.3109/ 09637480801990389

99. Bilezikian J, Davidson M, Hendrix S, Liu L, Louie M. Comorbidity of decreased bone mineral density (BMD) and increased cholesterol levels among women aged 65 years and older: results from NHANES III. ASBMR 27th Annual Meeting; 2005.

100. Saarinen A, Saukkonen T, Kivela T, et al. Low density lipoprotein receptor-related protein 5 (LRP5) mutations and osteoporosis, impaired glucose metabolism and hypercholesterolaemia. Clin Endocrinol (Oxf). 2010;72(4):481-488. doi:10.1111/j.13652265.2009.03680.x

101. Hirasawa H, Tanaka S, Sakai A, et al. ApoE gene deficiency enhances the reduction of bone formation induced by a high-fat diet through the stimulation of p53-mediated apoptosis in osteoblastic cells. J Bone Miner Res. 2007;22(7):1020-1030. doi:10.1359/jbmr.070330

102. Parhami F, Tintut Y, Beamer WG, Gharavi N, Goodman W, Demer LL. Atherogenic high-fat diet reduces bone mineralization in mice. J Bone Miner Res. 2001;16(1):182-188. doi:10.1359/ jbmr.2001.16.1.182

103. Turek JJ, Watkins BA, Schoenlein IA, Allen KG, Hayek MG, Aldrich CG. Oxidized lipid depresses canine growth, immune function, and bone formation. $J$ Nutr Biochem. 2003;14 (1):24-31. doi:10.1016/S0955-2863(02)00221-8

104. Pirih F, Lu J, Ye F, et al. Adverse effects of hyperlipidemia on bone regeneration and strength. J Bone Miner Res. 2012;27 (2):309-318. doi:10.1002/jbmr.541

105. Pelton K, Krieder J, Joiner D, Freeman MR, Goldstein SA, Solomon KR. Hypercholesterolemia promotes an osteoporotic phenotype. Am J Pathol. 2012;181(3):928-936. doi:10.1016/j. ajpath.2012.05.034

106. Uzzan B, Cohen R, Nicolas P, Cucherat M, Perret GY. Effects of statins on bone mineral density: a meta-analysis of clinical studies. Bone. 2007;40(6):1581-1587. doi:10.1016/j.bone.2007.02.019

107. Majima T, Komatsu Y, Fukao A, Ninomiya K, Matsumura T, Nakao K. Short-term effects of atorvastatin on bone turnover in male patients with hypercholesterolemia. Endocr J. 2007;54 (1):145-151. doi:10.1507/endocrj.K06-127

108. Solomon DH, Finkelstein JS, Wang PS, Avorn J. Statin lipid-lowering drugs and bone mineral density. Pharmacoepidemiol Drug Saf. 2005;14(4):219-226. doi:10.1002/pds.984

109. Tian L, Yu X. Lipid metabolism disorders and bone dysfunction interrelated and mutually regulated (review). Mol Med Rep. 2015;12(1):783-794. doi:10.3892/mmr.2015.3472

110. Shoback D. Update in osteoporosis and metabolic bone disorders. $J$ Clin Endocrinol Metab. 2007;92(3):747-753. doi:10.1210/ jc.2007-0042

111. Raisz LG. Pathogenesis of osteoporosis: concepts, conflicts, and prospects. J Clin Invest. 2005;115(12):3318-3325. doi:10.1172/ JCI27071 
112. You L, Sheng ZY, Tang CL, Chen L, Pan L, Chen JY. High cholesterol diet increases osteoporosis risk via inhibiting bone formation in rats. Acta Pharmacol Sin. 2011;32(12):1498-1504. doi:10.1038/aps.2011.135

113. Xiao Y, Cui J, Li YX, Shi YH, Le GW. Expression of genes associated with bone resorption is increased and bone formation is decreased in mice fed a high-fat diet. Lipids. 2010;45 (4):345-355. doi:10.1007/s11745-010-3397-0

114. Yavropoulou MP, Yovos JG. The role of the Wnt signaling pathway in osteoblast commitment and differentiation. Hormones (Athens). 2007;6(4):279-294. doi:10.14310/horm.2002.1111024

115. Janssens K, Ten Dijke P, Janssens S, Van Hul W. Transforming growth factor-betal to the bone. Endocr Rev. 2005;26 (6):743-774.

116. Groeneveld EH, Burger EH. Bone morphogenetic proteins in human bone regeneration. Eur J Endocrinol. 2000;142(1):9-21. doi:10.1530/eje.0.1420009

117. Tankò LB, Bagger YZ, Christiansen C. Low bone mineral density in the hip as a marker of advanced atherosclerosis in elderly women. Calcif Tissue Int. 2003;73(1):15-20. doi:10.1007/s00223-002-2070-x

118. Navab M, Hama SY, Cooke CJ, et al. Normal high density lipoprotein inhibits three steps in the formation of mildly oxidized low density lipoprotein: step 1. J Lipid Res. 2000;41 (9):1481-1494.

119. Almeida M, Ambrogini E, Han L, Manolagas SC, Jilka RL. Increased lipid oxidation causes oxidative stress, increased peroxisome proliferator-activated receptor-gamma expression, and diminished pro-osteogenic Wnt signaling in the skeleton. $J$ Biol Chem. 2009;284(40):27438-27448. doi:10.1074/jbc.M109.023572

120. Mody N, Parhami F, Sarafian TA, Demer LL. Oxidative stress modulates osteoblastic differentiation of vascular and bone cells Free Radic Biol Med. 2001;31(4):509-519. doi:10.1016/S08915849(01)00610-4

121. Brodeur MR, Brissette L, Falstrault L, Ouellet P, Moreau R. Influence of oxidized low-density lipoproteins (LDL) on the viability of osteoblastic cells. Free Radic Biol Med. 2008;44 (4):506-517. doi:10.1016/j.freeradbiomed.2007.08.030

122. Campos RM, de Piano A, da Silva PL, et al. The role of pro/ anti-inflammatory adipokines on bone metabolism in NAFLD obese adolescents: effects of long-term interdisciplinary therapy. Endocrine. 2012;42(1):146-156. doi:10.1007/s12020-012-9613-3

123. Graham LS, Tintut Y, Parhami F, et al. Bone density and hyperlipidemia: the T-lymphocyte connection. J Bone Miner Res. 2010;25(11):2460-2469. doi:10.1002/jbmr.148

124. Yang R-L, Shi Y-H, Hao G, Li W, Le G-W. Increasing oxidative stress with progressive hyperlipidemia in human: relation between malondialdehyde and atherogenic index. $J$ Clin Biochem Nutr. 2008;43(3):154-158. doi:10.3164/jcbn.2008044

125. Al-Waili NS. Natural honey lowers plasma glucose, C-reactive protein, homocysteine, and blood lipids in healthy, diabetic, and hyperlipidemic subjects: comparison with dextrose and sucrose. J Med Food. 2004;7(1):100-107. doi:10.1089/109662004322984789

126. Hemmati M, Karamian M, Malekaneh M. Anti-atherogenic potential of natural honey: anti-diabetic and antioxidant approaches. J Pharm Pharmacol. 2015;3:278-284.

127. Altinkaynak NÖ. Effects of mad honey on blood glucose and lipid levels in rats with streptozocin-induced diabetes. Turk $J$ Vet Anim Sci. 2005;2005(29):1093-1096.

128. Erejuwa OO, Nwobodo NN, Akpan JL, et al. Nigerian honey ameliorates hyperglycemia and dyslipidemia in alloxan-induced diabetic rats. Nutrients. 2016;8(3):95. doi:10.3390/nu8030095

129. Stanhope KL, Schwarz JM, Keim NL, et al. Consuming fructose-sweetened, not glucose-sweetened, beverages increases visceral adiposity and lipids and decreases insulin sensitivity in overweight/obese humans. J Clin Invest. 2009;119(5):1322-1334. doi:10.1172/JCI37385
130. Jurgens $\mathrm{H}$, Haass $\mathrm{W}$, Castaneda TR, et al. Consuming fructose-sweetened beverages increases body adiposity in mice. Obes Res. 2005;13(7):1146-1156. doi:10.1038/oby.2005.136

131. Busserolles J, Gueux E, Rock E, Mazur A, Rayssiguier Y. Substituting honey for refined carbohydrates protects rats from hypertriglyceridemic and prooxidative effects of fructose. J Nutr. 2002;132(11):3379-3382. doi:10.1093/jn/132.11.3379

132. Chepulis L, Starkey N. The long-term effects of feeding honey compared with sucrose and a sugar-free diet on weight gain, lipid profiles, and DEXA measurements in rats. J Food Sci. 2008;73 (1):H1-7. doi:10.1111/j.1750-3841.2007.00592.x

133. Nordestgaard BG. Triglyceride-rich lipoproteins and atherosclerotic cardiovascular disease: new insights from epidemiology, genetics, and biology. Circ Res. 2016;118(4):547-563. doi:10.1161/CIRCRESAHA.115.306249

134. Shapiro MD, Fazio S. From lipids to inflammation: new approaches to reducing atherosclerotic risk. Circ Res. 2016;118 (4):732-749. doi:10.1161/CIRCRESAHA.115.306471

135. Khalil MI, Tanvir EM, Afroz R, Sulaiman SA, Gan SH. Cardioprotective effects of tualang honey: amelioration of cholesterol and cardiac enzymes levels. Biomed Res Int. 2015;2015:286051. doi:10.1155/2015/286051

136. Aziz MSA, Giribabu N, Rao PV, Salleh N. Pancreatoprotective effects of geniotrigona thoracica stingless bee honey in streptozotocin-nicotinamide-induced male diabetic rats. Biomed Pharmacother. 2017;89:135-145. doi:10.1016/j. biopha.2017.02.026

137. Amir G, Rosenmann E, Sherman Y, Greenfeld Z, Ne'eman Z, Cohen AM. Osteoporosis in the cohen diabetic rat: correlation between histomorphometric changes in bone and microangiopathy. Lab Invest. 2002;82(10):1399-1405. doi:10.1097/01.LAB.0000032378.19165.E2

138. Hossain M, Faruque MO, Kabir G, et al. Association of serum TNF- $\alpha$ and IL- 6 with insulin secretion and insulin resistance in IFG and IGT subjects in a Bangladeshi population. Int J Diabetes Mellit. 2010;2(3):165-168. doi:10.1016/j.ijdm.2010.08.004

139. Kayal RA, Tsatsas D, Bauer MA, et al. Diminished bone formation during diabetic fracture healing is related to the premature resorption of cartilage associated with increased osteoclast activity. J Bone Miner Res. 2007;22(4):560-568. doi:10.1359/ jbmr.070115

140. Botolin S, Faugere MC, Malluche H, Orth M, Meyer R, McCabe LR. Increased bone adiposity and peroxisomal proliferator-activated receptor-gamma2 expression in type I diabetic mice. Endocrinology. 2005;146(8):3622-3631. doi:10.1210/en.2004-1677

141. Ward DT, Yau SK, Mee AP, et al. Functional, molecular, and biochemical characterization of streptozotocin-induced diabetes. J Am Soc Nephrol. 2001;12(4):779-790.

142. American Diabetes Association. Diagnosis and classification of diabetes mellitus. Diabetes Care. 2009;32(Suppl 1):S62-67.

143. Jiao H, Xiao E, Graves DT. Diabetes and its effect on bone and fracture healing. Curr Osteoporos Rep. 2015;13(5):327-335. doi:10.1007/s11914-015-0286-8

144. Shah VN, Shah CS, Snell-Bergeon JK. Type 1 diabetes and risk of fracture: meta-analysis and review of the literature. Diabet Med. 2015;32(9):1134-1142. doi:10.1111/dme.12734

145. Petit MA, Paudel ML, Taylor BC, et al. Bone mass and strength in older men with type 2 diabetes: the osteoporotic fractures in men study. J Bone Miner Res. 2010;25(2):285-291. doi:10.1359/ jbmr.090725

146. Yamaguchi T, Kanazawa I, Yamamoto M, et al. Associations between components of the metabolic syndrome versus bone mineral density and vertebral fractures in patients with type 2 diabetes. Bone. 2009;45(2):174-179. doi:10.1016/j. bone.2009.05.003 
147. Moayeri A, Mohamadpour M, Mousavi SF, Shirzadpour E, Mohamadpour S, Amraei M. Fracture risk in patients with type 2 diabetes mellitus and possible risk factors: a systematic review and meta-analysis. Ther Clin Risk Manag. 2017;13:455-468. doi:10.2147/TCRM.S131945

148. Yaturu S, Humphrey S, Landry C, Jain SK. Decreased bone mineral density in men with metabolic syndrome alone and with type 2 diabetes. Med Sci Monit. 2009;15(1):CR5-9.

149. Gupta M. A study on the effect of high glucose on osteoblasts like cell proliferation and apoptosis. Int $J$ Pharm Biol. 2014;5:3862-3866.

150. Guerra-Menéndez L, Sádaba MC, Puche JE. IGF-I increases markers of osteoblastic activity and reduces bone resorption via osteoprotegerin and RANK-ligand. J Transl Med. 2013;11 (1):271. doi:10.1186/1479-5876-11-271

151. Klein GL. Insulin and bone: recent developments. World J Diabetes. 2014;5(1):14-16. doi:10.4239/wjd.v5.i1.14

152. Mohan S, Baylink DJ. Impaired skeletal growth in mice with haploinsufficiency of IGF-I: genetic evidence that differences in IGF-I expression could contribute to peak bone mineral density differences. J Endocrinol. 2005;185(3):415-420. doi:10.1677/ joe. 1.06141

153. Zhang M, Xuan S, Bouxsein ML, et al. Osteoblast-specific knockout of the insulin-like growth factor (IGF) receptor gene reveals an essential role of IGF signaling in bone matrix mineralization. $J$ Biol Chem. 2002;277(46):44005-44012. doi:10.1074/jbc.M208265200

154. Chin KY, Ima-Nirwana S, Mohamed IN, et al. Insulin-like growth factor-1 is a mediator of age-related decline of bone health status in men. Aging Male. 2014;17(2):102-106. doi:10.3109/ 13685538.2014.896895

155. Jackuliak P, Payer J. Osteoporosis, fractures, and diabetes. Int J Endocrinol. 2014;2014:820615. doi:10.1155/2014/820615

156. Schneider D, Gauthier B, Trachtman H. Hypercalciuria in children with renal glycosuria: evidence of dual renal tubular reabsorptive defects. $J$ Pediatr. 1992;121(5 Pt 1):715-719. doi:10.1016/S0022-3476(05)81898-0

157. Vashishth D. Advanced glycation end-products and bone fractures. IBMS BoneKEy. 2009;6(8):268-278. doi:10.1138/ 20090390

158. Viguet-Carrin S, Farlay D, Bala Y, Munoz F, Bouxsein ML, Delmas PD. An in vitro model to test the contribution of advanced glycation end products to bone biomechanical properties. Bone. 2008;42(1):139-149. doi:10.1016/j.bone.2007.08.046

159. Li Z, Li C, Zhou Y, et al. Advanced glycation end products biphasically modulate bone resorption in osteoclast-like cells. Am J Physiol Endocrinol Metab. 2016;310(5):E355-366. doi:10.1152/ajpendo.00309.2015

160. Kume S, Kato S, Yamagishi S, et al. Advanced glycation end-products attenuate human mesenchymal stem cells and prevent cognate differentiation into adipose tissue, cartilage, and bone. J Bone Miner Res. 2005;20(9):1647-1658. doi:10.1359/ JBMR.050514

161. Alamshah A, Spreckley E, Norton M, et al. 1-phenylalanine modulates gut hormone release and glucose tolerance, and suppresses food intake through the calcium-sensing receptor in rodents. Int $J$ Obes (Lond). 2017;41(11):1693-1701. doi:10.1038/ijo.2017.164

162. Erejuwa OO, Sulaiman SA, Wahab MS, Sirajudeen KN, Salleh MS, Gurtu S. Antioxidant protection of Malaysian tualang honey in pancreas of normal and streptozotocin-induced diabetic rats. Ann Endocrinol (Paris). 2010;71(4):291-296. doi:10.1016/j. ando.2010.03.003

163. Arabmoazzen S, Sarkaki A, Saki G, Mirshekar MA. Antidiabetic effect of honey feeding in noise induced hyperglycemic rat: involvement of oxidative stress. Iran J Basic Med Sci. 2015;18 (8):745-751.
164. Vallianou NG, Gounari P, Skourtis A, Panagos J, Kazazis C. 2. Honey and its anti-inflammatory, anti-bacterial and anti-oxidant properties. Gen Med Open Access. 2014;2(1):132.

165. Al-Waili N, Salom K, Al-Ghamdi A, Ansari MJ, Al-Waili A, AlWaili T. Honey and cardiovascular risk factors, in normal individuals and in patients with diabetes mellitus or dyslipidemia. J Med Food. 2013;16(12):1063-1078. doi:10.1089/jmf.2012.0285

166. Krishnasree V, Ukkuru MP. In vitro antidiabetic activity and glycemic index of bee honeys. Indian $J$ Tradit Knowl. 2017;16:134-140.

167. Agarwal P, Gupta R. Alpha-amylase inhibition can treat diabetes mellitus. Res Rev J Med Health Sci. 2016;5(4):1-8.

168. Ganeshpurkar A, Diwedi V, Bhardwaj Y. In vitro $\alpha$-amylase and $\alpha$-glucosidase inhibitory potential of Trigonella foenum-graecum leaves extract. Ayu. 2013;34(1):109-112. doi:10.4103/09748520.115446

169. Sonia TA, Sharma CP. 1 - Diabetes mellitus - an overview. In: Sonia TA, Sharma CP, editors. Oral Delivery of Insulin. Woodhead Publishing; 2014:1-57.

170. Gordan R, Gwathmey JK, Xie LH. Autonomic and endocrine control of cardiovascular function. World J Cardiol. 2015;7 (4):204-214. doi:10.4330/wjc.v7.i4.204

171. Sata Y, Head GA, Denton K, May CN, Schlaich MP. Role of the sympathetic nervous system and its modulation in renal hypertension. Front Med. 2018;5:82. doi:10.3389/ fmed.2018.00082

172. Landsberg L, Aronne LJ, Beilin LJ, et al. Obesity-related hypertension: pathogenesis, cardiovascular risk, and treatment-a position paper of the the obesity society and the american society of hypertension. Obesity (Silver Spring). 2013;21(1):8-24. doi:10.1002/oby.20181

173. Landsberg L. Insulin-mediated sympathetic stimulation: role in the pathogenesis of obesity-related hypertension (or, how insulin affects blood pressure, and why). J Hypertens. 2001;19(3 Pt 2):523-528. doi:10.1097/00004872-200103001-00001

174. Jalal DI, Smits G, Johnson RJ, Chonchol M. Increased fructose associates with elevated blood pressure. J Am Soc Nephrol. 2010;21(9):1543-1549. doi:10.1681/ASN.2009111111

175. Bourgoin F, Bachelard H, Badeau M, et al. Endothelial and vascular dysfunctions and insulin resistance in rats fed a high-fat, high-sucrose diet. Am J Physiol Heart Circ Physiol. 2008;295(3):H1044-h1055. doi:10.1152/ ajpheart.00516.2008

176. Schulz E, Gori T, Munzel T. Oxidative stress and endothelial dysfunction in hypertension. Hypertens Res. 2011;34 (6):665-673. doi:10.1038/hr.2011.39

177. Rodrigo R, González J, Paoletto F. The role of oxidative stress in the pathophysiology of hypertension. Hypertens Res. 2011;34 (4):431-440. doi:10.1038/hr.2010.264

178. Hamza SM, Dyck JRB. Systemic and renal oxidative stress in the pathogenesis of hypertension: modulation of long-term control of arterial blood pressure by resveratrol. Front Physiol. 2014;5:292. doi:10.3389/fphys.2014.00292

179. Rojo AI, Rada P, Egea J, Rosa AO, López MG, Cuadrado A. Functional interference between glycogen synthase kinase-3 beta and the transcription factor $\mathrm{Nrf2}$ in protection against kainate-induced hippocampal cell death. Mol Cell Neurosci. 2008;39(1):125-132. doi:10.1016/j.mcn.2008.06.007

180. Metz JA, Karanja N, Young EW, Morris CD, McCarron DA. Bone mineral density in spontaneous hypertension: differential effects of dietary calcium and sodium. Am J Med Sci. 1990;300 (4):225-230. doi:10.1097/00000441-199010000-00005

181. Bastos MF, Brilhante FV, Bezerra JP, Silva CA, Duarte PM. Trabecular bone area and bone healing in spontaneously hypertensive rats: a histometric study. Braz Oral Res. 2010;24 (2):170-176. doi:10.1590/S1806-83242010000200008 
182. Cappuccio FP, Meilahn E, Zmuda JM, Cauley JA. High blood pressure and bone-mineral loss in elderly white women: a prospective study. Study of osteoporotic fractures research group. Lancet. 1999;354(9183):971-975. doi:10.1016/S0140-6736(99)01437-3

183. Yang S, Nguyen ND, Center JR, Eisman JA, Nguyen TV. Association between hypertension and fragility fracture: a longitudinal study. Osteoporos Int. 2014;25(1):97-103. doi:10.1007/s00198-013-2457-8

184. Ye Z, Lu H, Liu P. Association between essential hypertension and bone mineral density: a systematic review and meta-analysis Oncotarget. 2017;8(40):68916-68927. doi:10.18632/ oncotarget. 20325

185. Gotoh M, Mizuno K, Ono Y, Takahashi M. High blood pressure, bone-mineral loss and insulin resistance in women. Hypertens Res. 2005;28(7):565-570. doi:10.1291/hypres.28.565

186. Vanderschueren D, Boonen S, Bouillon R. Physiology of calcium homeostasis and bone remodeling. In: Geusens P, Sambrook PN, Lindsay R, editors. Osteoporosis in Clinical Practice: A Practical Guide for Diagnosis and Treatment. London: Springer London; 2004:9-14.

187. Kesteloot H, Tzoulaki I, Brown IJ, et al. Relation of urinary calcium and magnesium excretion to blood pressure: the international study of macro- and micro-nutrients and blood pressure and the international cooperative study on salt, other factors, and blood pressure. Am J Epidemiol. 2011;174(1):44-51. doi:10.1093/aje/kwr049

188. McCarron DA, Pingree PA, Rubin RJ, Gaucher SM, Molitch M, Krutzik S. Enhanced parathyroid function in essential hypertension: a homeostatic response to a urinary calcium leak. Hypertension. 1980;2(2):162-168. doi:10.1161/01.HYP.2.2.162

189. Gadallah M, Massry SG, Bigazzi R, Horst RL, Eggena P, Campese VM. Intestinal absorption of calcium and calcium metabolism in patients with essential hypertension and normal renal function. Am J Hypertens. 1991;4(5 Pt 1):404 409. doi:10.1093/ajh/4.5.404

190. Erejuwa OO, Sulaiman SA, Ab Wahab MS, Sirajudeen KNS, Salleh S, Gurtu S. Honey supplementation in spontaneously hypertensive rats elicits antihypertensive effect via amelioration of renal oxidative stress. Oxid Med Cell Longev. 2012;2012:374037. doi:10.1155/2012/374037

191. Erejuwa OO, Sulaiman SA, Wahab MS, Sirajudeen KN, Salleh MS, Gurtu S. Differential responses to blood pressure and oxidative stress in streptozotocin-induced diabetic Wistar-Kyoto rats and spontaneously hypertensive rats: effects of antioxidant (honey) treatment. Int $J$ Mol Sci. 2011;12 (3):1888-1907. doi:10.3390/ijms12031888

192. Al-Waili N. Intrapulmonary administration of natural honey solution, hyperosmolar dextrose or hypoosmolar distill water to normal individuals and to patients with type-2 diabetes mellitus or hypertension: their effects on blood glucose level, plasma insulin and C-peptide, blood pressure and peaked expiratory flow rate. Eur J Med Res. 2003;8(7):295-303.

193. Aluko EO, Olubobokun TH, Enobong IB, Atang DE. Comparative study of effect of honey on blood pressure and heart rate in healthy male and female subjects. $\mathrm{Br} J \mathrm{Med}$ Med Res. 2013;3(4):2214-2221. doi:10.9734/BJMMR/2013/4152

194. Aluko EO, Olubobokun TH, Atang DE, Nna VU. Honey's ability to reduce blood pressure and heart rate in healthy male subjects. Front Sci. 2014;4:8-11.

195. Trivedi R, Kumar S, Kumar A, et al. Kaempferol has osteogenic effect in ovariectomized adult sprague-dawley rats. Mol Cell Endocrinol. 2008;289(1-2):85-93. doi:10.1016/j.mce.2008.02.027

196. Zaid SSM, Sulaiman SA, Sirajudeen KNM, Othman NH. The effects of tualang honey on female reproductive organs, tibia bone and hormonal profile in ovariectomised rats-animal model for menopause. BMC Complement Altern Med. 2010;10(1):82. doi:10.1186/1472-6882-10-82
197. Lily Husniata Y. The effects of tualang honey on postmenopausal women. 2nd International Conference on the Medicinal Use of Honey; 2010; Renaissance Hotel, Kota Bharu, Kelantan, Malaysia.

198. Yudaniayanti IS, Primarizky H, Nangoi L. The effects of honey (Apis dorsata) supplements on increased bone strength in ovariectomized rat as animal model of osteoporosis. AIP Conf Proc. 2018;1945(1):020004.

199. Kamaruzzaman MA, Thanu A, Yusof MR, Soelaiman IN, Ramli ES. Kelulut honey ameliorates glucocorticoid induced osteoporosis via its antioxidant activity in rats. Asian Pac J Trop Biomed. 2019;9(12):493-500. doi:10.4103/2221-1691.271722

200. Sheweita SA, Khoshhal KI, Baghdadi HH. Osteoporosis and oxidative stress - role of antioxidants. In: Laher I, editor. Systems Biology of Free Radicals and Antioxidants. Berlin, Heidelberg: Springer Berlin Heidelberg; 2014:2973-2995.

201. Jaganathan SK, Mandal M. Antiproliferative effects of honey and of its polyphenols: a review. $J$ Biomed Biotechnol. 2009;2009:830616. doi:10.1155/2009/830616

202. Cornara L, Biagi M, Xiao J, Burlando B. Therapeutic properties of bioactive compounds from different honeybee products. Front Pharmacol. 2017;8:412. doi:10.3389/fphar.2017.00412

203. Chen JR, Lazarenko OP, Wu X, et al. Dietary-induced serum phenolic acids promote bone growth via $\mathrm{p} 38 \mathrm{MAPK} /$ beta-catenin canonical Wnt signaling. $J$ Bone Miner Res. 2010;25 (11):2399-2411. doi:10.1002/jbmr.137

204. Wattel A, Kamel S, Mentaverri R, et al. Potent inhibitory effect of naturally occurring flavonoids quercetin and kaempferol on in vitro osteoclastic bone resorption. Biochem Pharmacol. 2003;65(1):35-42. doi:10.1016/S0006-2952(02)01445-4

205. Ibrahim MHR, Hasib AH, Rohmah SN, Abani S, Yordan S, Yudaniayanti IS. Utilization of honey apis dorsata as antiosteoporosis on requirements of bone calcium ash density on ovariohysterectomized white rat (ratus norvegicus). KnE Life Sci. 2017;3(6):627. doi:10.18502/kls.v3i6.1191

206. Jeffrey A, Echazarreta C. Medical uses of honey. Rev Biomed. 1996;7:43-49.

207. Tsukahara T, Koyama H, Okada M, Ushida K. Stimulation of butyrate production by gluconic acid in batch culture of pig cecal digesta and identification of butyrate-producing bacteria. $J$ Nutr. 2002;132(8):2229-2234. doi:10.1093/jn/132.8.2229

208. Donohoe DR, Garge N, Zhang X, et al. The microbiome and butyrate regulate energy metabolism and autophagy in the mammalian colon. Cell Metab. 2011;13(5):517-526. doi:10.1016/j. cmet.2011.02.018

209. Million M, Armstrong N, Khelaifia S, et al. The antioxidants glutathione, ascorbic acid and uric acid maintain butyrate production by human gut clostridia in the presence of oxygen in vitro. Sci Rep. 2020;10(1):7705. doi:10.1038/s41598-020-64834-3

210. Cleophas MCP, Ratter JM, Bekkering S, et al. Effects of oral butyrate supplementation on inflammatory potential of circulating peripheral blood mononuclear cells in healthy and obese males. Sci Rep. 2019;9(1):775. doi:10.1038/s41598-018-37246-7

211. Gao F, Lv Y-W, Long J, et al. Butyrate improves the metabolic disorder and gut microbiome dysbiosis in mice induced by a high-fat diet. Front Pharmacol. 2019;10:1040. doi:10.3389/ fphar.2019.01040

212. Li L, Rao S, Cheng Y, et al. Microbial osteoporosis: the interplay between the gut microbiota and bones via host metabolism and immunity. MicrobiologyOpen. 2019;8(8):e00810-e00810. doi: $10.1002 / \mathrm{mbo} 3.810$

213. Weaver CM. Diet, gut microbiome, and bone health. Curr Osteoporos Rep. 2015;13(2):125-130. doi:10.1007/s11914-015-0257-0

214. Chen YC, Greenbaum J, Shen H, Deng HW. Association between gut microbiota and bone health: potential mechanisms and prospective. J Clin Endocrinol Metab. 2017;102(10):3635-3646. doi:10.1210/jc.2017-00513 


\section{Publish your work in this journal}

Diabetes, Metabolic Syndrome and Obesity: Targets and Therapy is an international, peer-reviewed open-access journal committed to the rapid publication of the latest laboratory and clinical findings in the fields of diabetes, metabolic syndrome and obesity research. Original research, review, case reports, hypothesis formation, expert opinion and commentaries are all considered for publication. The manuscript management system is completely online and includes a very quick and fair peer-review system, which is all easy to use. Visit http://www.dovepress.com/testimonials.php to read real quotes from published authors.

Submit your manuscript here: https://www.dovepress.com/diabetes-metabolic-syndrome-and-obesity-targets-and-therapy-journal 